\title{
PERANCANGAN SISTEM INFORMASI ADMINISTRASI PEMBAYARAN PADA SEKOLAH ALAM AKHDHOR INSAN MULIA
}

\author{
Putri Nurdianawati $^{1}$, Fibria Anggraini Puji Lestari ${ }^{2}$ \\ Program Studi Teknik Informatika, Fakultas Teknik dan Ilmu Komputer, \\ Universitas Indraprasta PGRI \\ Jalan Raya Tengah No 80, Kelurahan Gedong, Pasar Rebo, Jakarta Timur \\ pnurdianawati@gmail.com¹, fibria981@gmail.com²
}

\begin{abstract}
Abstrak
Permasalah yang terdapat pada Sekolah Alam Akhdhor Insan Mulia bagian tata usaha yaitu pengolahan data nya masih menggunakan kertas yang berupa kartu untuk proses pembayaran. Dengan adanya pengolahan data tersebut mengakibatkan kurangnya efisien waktu, ketepatan data, perhitungan data, serta keakuratan data. Dalam hal pendataan keuangan belum menggunakan aplikasi sehingga informasi dilakukan kurang akurat dan kemungkinan terjadi kesalahan dalam proses pendataan. Sedangkan dalam pengolahan informasi administrasi pembayaran siswa masih menggunakan input data secara manual, sehingga pemanfaatannya kurang optimal. Apabila terlalu lama dalam proses pengolahan informasi akan mengakibatkan keterlambatan dalam pengambilan keputusan. Tujuan penelitian ini yaitu untuk merancang sistem informasi administrasi pembayaran secara terkomputerisasi, membuat sistem informasi administrasi pembayaran yang dapat mengolah informasi secara optimal, dan membuat suatu sistem informasi administrasi pembayaran yang dapat melakukan pendataan secara akurat dan tepat sehingga tidak terjadi kesalahan dalam proses pendataan. Metode yang digunakan dalam penelitian ini yaitu metode grounded dengan metode pengumpulan data nya melalui observasi, wawancara, dan studi pustaka. Hasil dari penelitian yang telah dilakukan adalah sebuah sistem informasi administrasi pembayaran yang telah terkomputerisasi.
\end{abstract}

Kata Kunci :Administrasi pembayaran, Java, MySQL, Netbeans.

\begin{abstract}
The problem with the Alam Akhdhor Insan Mulia School in the administration section is that the data processing still uses paper in the form of cards for payment processing. With this data processing resulted in a lack of time efficiency, data accuracy, data calculation, and data accuracy. In terms of financial data collection, the application has not been used so that the information is not accurate and there may be errors in the data collection process. Meanwhile, in processing payment administration information, students still use manual data input, so that the utilization is not optimal. If it is too long in the information processing process, it will result in delays in decision making. The purpose of this study is to design a computerized payment administration information system, create a payment administration information system that can process information optimally, and create a payment administration information system that can collect data accurately and precisely so that there are no errors in the data collection process. The method used in this study is the grounded method with data collection methods through observation, interviews, and literature study. The result of the research that has been done is a computerized payment administration information system.
\end{abstract}

Keyword: Payment administration, Java, MySQL, Netbeans

\section{PENDAHULUAN}

Sekolah Alam Akhdor Insan Mulia merupakan sekolah dasar yang menggunakan metode pembelajaran alam dengan tujuan agar para murid bisa menanamkan jiwa leadership atau berjiwa pemimpin baik untuk dirinya maupun lingkungannya. Namun terdapat beberapa masalah pada bagian tata usaha Sekolah Alam Akhdhor Insan Mulia yaitu pengolahan data nya masih menggunakan kertas yang berupa kartu untuk proses pembayaran. Dengan adanya pengolahan data tersebut mengakibatkan kurangnya efisien waktu, ketepatan data, perhitungan data, serta keakuratan data. Dalam hal pendataan keuangan Sekolah Alam Akhdhor Insan Mulia belum menggunakan aplikasi sehingga informasi dilakukan kurang akurat dan kemungkinan terjadi kesalahan dalam proses pendataan. Sedangkan dalam pengolahan informasi administrasi pembayaran siswa masih menggunakan input data secara manual, sehingga pemanfaatannya kurang optimal. Dan apabila terlalu lama dalam proses 
pengolahan informasi akan mengakibatkan keterlambatan dalam pengambilan keputusan. Dari beberapa masalah yang ada Sekolah Alam Akhdhor Insan Mulia membutuhkan sistem informasi berbasis komputer untuk mengurangi permasalahan permasalahan yang ada sebelumnya. Adapun tujuan penelitian ini yaitu untuk merancang sistem informasi administrasi pembayaran secara terkomputerisasi, membuat sistem informasi administrasi pembayaran yang dapat mengolah informasi secara optimal, dan membuat suatu sistem informasi administrasi pembayaran yang dapat melakukan pendataan secara akurat dan tepat sehingga tidak terjadi kesalahan dalam proses pendataan. Sistem administrasi pembayaran dibuat untuk memudahkan pengguna dalam hal pengolahan informasi, dan pengolahan data. Menurut Al Fatta (2015) dalam (Fitriowandi, 2018) perancangan merupakan suatu keputusan dalam hal organisasi sebuah sistem menjadi subsistem dengan menggunakan stategi tingkat tinggi. Sistem Informasi menurut Sutabri (2012) dalam (Lubis, 2016) merupakan sebuah sistem yang berada pada suatu organisasi yang menyatukan kebutuhan pengolahan transaksi harian dan mendukung fungsi operasi organisasi yang bersifat manajerial dengan kegiatan strategi dari suatu organisasi untuk dapat menyediakan kepada suatu pihak dengan laporan yang dibutuhkan. Data Flow Diagram (DFD) menurut Diana dan Setiawati (2011) dalam (Abdullah, 2015) merupakan suatu penggambaran komponen suatu sistem, aliran data berada pada komponen sistem sumber data, tujuan, dan penyimpanan data. Menurut Hendra dkk (2011) dalam (Rusmana et al., 2014) bahwa java merupakan suatu bahasa pemrograman yang dapat dijalankan dalam sebuah perangkat komputer, termasuk pada ponsel atau dengan kata lain bahasa pemrograman yang berorientasi objek (OOP) yang dapat dijalankan pada berbagai platform sistem operasi. Menurut Kurniawan (2011) dalam (Kuryanti, 2014) bahwa netbeans merupakan sebuah software yang digunakan untuk membuat suatu aplikasi yang berbasis java. Software ini digunakan sebagai media untuk menjalankan program lalu software ini mempermudah kita untuk melihat kesalahan dari program tersebut. Menurut Lagin (2010) dalam (Dewi \& Malfiany, 2017) administrasi merupakan sebuah keseluruhan proses kerja sama yang melibatkan dua orang atau lebih atas dasar rasionalitas tertentu untuk mencapai tujuan yang telah ditentukan sebelumnya. Menurut Jogiyanto (2010) dalam ( Mulyanto, 2015) bahwa pembayaran juga merupakan pemindahan suatu dana untuk dapat memenuhi suatu kewajiban yang timbul dari suatu kegiatan ekonomi.

\section{PENELITIAN RELEVAN}

Penelitian yang relevan dengan administrasi pembayaran yang sebelumnya sudah dilakukan penelitian diantaranya yaitu hasil penelitian dari (Mulyanto, 2015) dengan judul Rancang Bangun Sistem Informasi Pembayaran Mahasiswa, Jurnal Informasi dan Komputer E - ISSN : 2623-1247 No:1 Vol: 8. Latar belakang dari penelitian ini yaitu pada Universitas Megou Pak Tulang Bawang sistem pengolahan data yang digunakan khususnya pengolahan data pembayaran masih dilakukan dengan menggunakan program terapan dan belum digunakannya format database. Adapun pencarian data yang telah dimasukkan masih sulit disajikan karena data disimpan secara manual (data dalam bentuk arsip), sehingga terdapat kendala yang dihadapi seperti : proses pencarian data, perubahan data maupun rekap laporan masih membutuhkan waktu yang relatif lama dan memungkinkan terjadinya kesalahan (human error) karena rekap data dilakukan berdasarkan arsip. Untuk mengatasi masalah tersebut perlu diusulkan suatu sistem baru yang dapat membantu memberikan peningkatan efektifitas dalam pembuatan laporan juga mampu memberikan suatu informasi yang baik, akurat, cepat dan tepat waktu. Berdasarkan latar belakang masalah sebelumnya, maka penulis merumuskan masalah sebagai berikut "bagaimana merancang sistem pembayaran pada Universitas Megou Pak Tulang Bawang" sehingga dapat melayani mahasiswa dengan baik dan dapat memperoleh data lebih cepat dan akurat. Metode pengumpulan data yang digunakan dalam menyusun serta melengkapi data adalah melalui proses wawancara, studi pustaka dan observasi. Sedangkan untuk metode pengembangan sistem yang digunakan adalah Siklus Hidup Pengembangan Sistem (System Development Life Cyle) dengan menggunakan model Waterfall. Hasil dari penelitian ini yaitu berupa sistem aplikasi yang baru dalam pengolahan data pembayaran pada Universitas Megoupak yang diharapkan dapat membantu dalam proses penginputan data pembayaran, yang meliputi menu input data jurusan, mahasiswa, rincian biaya dan pembayaran.

Selain itu juga merancang laporan data mahasiswa, dan laporan data pembayaran. Setelah itu terdapat juga pada jurnal milik (Baswananda, 2014) dengan judul Sistem Pembayaran SPP Berbasis Komputer Pada SMA Kesatrian 1 Semarang, ISSN : 0967070X. Latar belakang dari penelitian ini yaitu pada 
SMA Kesatrian 1 Semarang. Pada sistem informasi yang sedang berjalan proses pencatatan data SPP siswa masih mengacu pada dokumen yang masih berupa berkas atau arsip - arsip dan belum memiliki media penyimpanan yang tepat. Dengan adanya sistem informasi pembayaran SPP ini diharapkan dapat membantu aktivitas sekolah terutama bagian tatausaha dalam mengetahui keuangan pembayaran registrasi siswa dan pembayaran SPP dan juga menyajikannya ke dalam bentuk laporan registrasi siswa dengan cepat, mudah, dan akurat. Adapun tujuan penelitian yang hendak dicapai dalam penyusunan laporan penelitian ini yaitu dapat merancang dan membuat sistem informasi pembayaran SPP pada SMA Kesatrian 1 Semarang, dan sebagai kewajiban untuk memenuhi Tugas Akhir sebagai persyaratan akademik guna memperoleh gelar Sarjana Komputer Strata Satu. Metode pengembangan yang digunakan dalam penelitian ini yaitu metode SDLC sedangkan metode pengumpulan data yang digunakan yaitu dengan melakukan wawancara, observasi/pengamatan, dan studi kepustakaan. Hasil dari penelitian ini yaitu sistem pembayaran SPP pada SMA Kesatrian I dapat melakukan pendataan transaksi dengan lebih cepat, efektif, dan konsisten. Dengan adanya program yang lebih baik sehingga dapat mengurangi adanya duplikasi dan redudansi data, serta penyimpanan datanya menjadi lebih aman.

Jurnal terakhir yang menjadi acuan yaitu jurnal milik (Susanto, 2016) yang berjudul Perancangan Aplikasi Pembayaran SPP pada SMAN 1 Ambarawa Menggunakan Bahasa Pemrograman Visual Basic 6.0, Jurnal Konferensi Mahasiswa Sistem Informasi E - ISSN : 1098 - 6596 Vol : 4. Latar belakang pada penelitian ini yaitu dalam bidang administrasi keuangan pada SMA Negeri 1 Ambarawa masih mengalami kesulitan dikarenakan masih menggunakan cara manual. Sehingga informasi yang dihasilkan terkadang masih mengalami kekeliruan dan keterlambatan pembuatan laporan. Hal ini disebabkan terbatasnya sumber daya manusia dan banyaknya data yang dikelola. Dalam hal ini tentunya proses pengolahan harus diolah secara efektif, efisien dan proses pengolahan data yang dijalankan harus mudah dalam pengisian data, pemprosesan data dan pelaporannya. Sedangkan ditinjau dari kefektifan sebuah sistem baik dari segi manfaat, biaya, maupun waktu yang digunakan, kesemuanya itu harus dapat mendukung tercapainya pemenuhan akan informasi pengolahan data yang berkualitas. Rumusan masalah pada penelitian ini yaitu pembayaran dilakukan masih secara manual, transaksi pembayaran masih menggunakan ketikan manual yang membuat kurang efisien, serta dikarenakan pencatatan dilakukan secara manual, jadi keamanan data sering tidak terjaga sehingga terjadi kehilangan data yang menimbulkan kesalahan pada proses pembuatan laporan. Adapun tujuan dibuatnya program aplikasi ini adalah membuat sistem informasi pengolahan data pembayaran siswa SMA N 1 Ambarawa menggunakan Microsoft Visual Basic 6.0. Metode pengumpulan data yang digunakan adalah dengan melakukan metode observasi, metode wawancara, dan studi kepustakaan. Sedangkan metode penelitian yang digunakan yaitu menggunakan metode waterfall. Adapun hasil dari penelitian ini yaitu dengan dibuatnya sistem ini, dapat membantu petugas TU dalam pengolahan data yang berhubungan dengan pembayaran siswa. Data - data yang berhubungan dengan pembayaran siswa tersimpan dalam suatu database elektronik, sehingga akan mempermudah dalam pengambilan data kembali. Penyimpanan data secara elektronik akan membantu dalam melakukan penyimpanan data, perubahan data, penghapusan data, pencarian data dan pembuatan laporan. Pada ketiga penelitian merancang sisten pembayaran yang hanya dikhususkan oleh satu atau dua jenis pembayaran saja sehingga penulis mengembangkan sistem administrasi dan pembayaran yang didalamnya terdapat lebih dari dua jenis pembayaran yaitu pendataan siswa, pendataan kelas, pendataan ekstrakurikuler, administrasi pendaftaran siswa, administrasi pembayaran spp, dan administrasi pembayaran ekstrakurikuler.

\section{METODE PENELITIAN}

Metode penelitian yang dilakukan oleh penulis yaitu sebagai berikut:

\section{Desain Penelitian}

Desain penelitian yang digunakan oleh penulis yaitu penelitian kualitatif dengan menggunakan metode grounded. Menurut Barnabas (2018) dalam (Trisnadi et al., 2020) mengungkapkan bahwa metode grounded yaitu suatu metode penelitian berdasarkan pada fakta dan menggunakan analisis perbandingan dengan tujuan mengadakan generalisasi empiris, menetapkan konsep, membuktikan teori, mengembangkan teori, pengumpulan dan analisis data dalam waktu yang bersamaan. 


\section{Metode Pengumpulan Data}

Metode pengumpulan data yang digunakan oleh penulis adalah sebagai berikut:

a. Observasi

Metode observasi merupakan metode pengumpulan data yang dilakukan dengan pengamatan langsung dan pengumpulan data yang dilakukan di Sekolah Alam Akhdhor Insan Mulia.

b. Wawancara

Metode wawancara dilakukan untuk melengkapi hasil pengamatan yang diperoleh melalui metode observasi. Wawancara dilakukan terhadap pihak - pihak yang berkompeten dengan permasalahan yang ada pada Sekolah Alam Akhdhor Insan Mulia.

c. Studi Pustaka

Metode studi pustaka merupakan metode pengumpulan data yang dilakukan dengan mengambil data - data dari buku serta jurnal yang dapat dijadikan sebagai landasan untuk menganalisa masalah yang ditemukan dalam penelitian.

\section{Langkah - Langkah Pengembangan Sistem}

Langkah - langkah pengembangan sistem yang digunakan oleh penulis yaitu:

a. Tahap Analisis Kebutuhan

Analisis kebutuhan berguna untuk mendapatkan data - data yang akan digunakan sebagai masukan dari suatu sistem dan untuk memperoleh data yang berhubungan dengan penelitian. Proses perancangan sistem informasi administrasi dan pembayaran sekolah dimulai dari memahami kebutuhan pengguna. Sebelum merancang sebuah sistem kita harus memahami kebutuhan pengguna, apa saja yang pengguna inginkan.

b. Tahap Sistem Desain

Menganalisis hubungan obyek dan fungsi pada sistem, menganalisa data untuk pembuatan skema database serta merancang user interface untuk pengembangan.

c. Tahap Perancangan Sistem

Perancangan sistem bertujuan untuk merancang sistem yang akan dibuat agar dapat diimplementasikan dengan kebutuhan pengguna. Langkah - langkah yang dilakukan dalam Perancangan Sistem Informasi Administrasi dan Pembayaran Pada Sekolah Alam Akhdor Insan Mulia berbasis Java adalah:

1) Merancang database

Dalam merancang sebuah database ini digunakan untuk menyimpan data - data yang telah dimasukkan atau diinput ke dalam sistem. Dalam merancang suatu database harus dilakukan beberapa tahapan, diantaranya:

a) Membuat tabel - tabel data beserta primary key - nya.

b) Menentukan Relationship dari setiap tabel.

c) Membuat Query.

d) Membuat report yang digunakan untuk menampilkan hasil output sebelum dicetak.

e) Membuat normalisasi jika terdapat tabel yang unnormal.

2) Merancang antarmuka

Di dalam merancang antarmuka ini, ada beberapa hal yang harus diperhatikan oleh perancang diantaranya:

a) Mengerti keinginan atau selera pengguna secara umum.

b) Harus memiliki jiwa seni.

c) Desain yang dibuat tidak terlalu rumit sehingga mudah dipahami oleh pengguna.

3) Melakukan evaluasi terdahap antarmuka

Evaluasi adalah bagian penting dari proses pengembangan, untuk mengetahui bagaimana tanggapan pengguna terhadap antarmuka yang telah dibuat. Evaluasi ini akan kita pergunakan untuk memperbaiki kekurangan pada antarmuka yang telah dibangun. Aturan dalam perancangan antarmuka yaitu:

a) Buatlah antarmuka yang mudah dipahami dan dikuasai oleh pengguna.

b) Buatlah antarmuka yang konsisten. 
d. Tahap Pengujian Program

Pengujian yaitu sebuah proses untuk memastikan apakah semua proses dapat bekerja dengan baik, mencari apakah masih terdapat kesalahan pada sistem. Pengujian sangat penting untuk menjamin kualitas dalam sistem dan juga menjadi peninjauan terakhir terhadap spesifikasi design dan pengkodean.

e. Tahap Evaluasi Sistem

Evaluasi penggunaan sistem merupakan bagian penting dari proses pengembangan untuk mengetahui bagaimana tanggapan pengguna terhadap tampilan antarmuka yang dibuat untuk pengguna yang menguasai sistem validasi meliputi:

1) Sistem yang dapat dibuat dapat memenuhi kebutuhan pengguna.

2) Implementasi pengkodean adalah proses menterjemahkan dokumen hasil - hasil design menjadi baris - baris perintah bahasa pemrograman komputer, semakin baik dari hasil analisis.

\section{HASIL DAN PEMBAHASAN}

\section{Analisis Permasalahan}

Dari hasil penelitian yang dilakukan, maka penulis dapat menganalisa permasalahan yang ada pada Sekolah Alam Akhdhor Insan Mulia yaitu pengolahan data masih menggunakan kertas yaitu berupa kartu, sehingga pengolahan datanya mengalami kendala dalam hal efisiensi, ketepatan data, perhitungan data, serta keakuratan data. Lalu, pendataan dilakukan belum menggunakan aplikasi, sehingga informasi yang dilakukan kurang akurat dan kemungkinan terjadi kesalahan dalam proses pendataan. Sekolah Alam Akhdhor Insan Mulia dalam pengolahan informasi administrasi pembayaran siswa masih menggunakan input data secara manual, sehingga pemanfaatannya kurang optimal. Serta terlalu lama dalam proses pengolahan informasi akan mengakibatkan keterlambatan dalam pengambilan keputusan.

\section{Alternatif Penyelesaian Masalah}

Berdasarkan masalah - masalah yang dihadapi dalam sistem administrasi pembayaran pada Sekolah Alam Akhdhor Insan Mulia, maka penulis memberikan alternatif masalah tersebut yaitu penulis membuat sistem informasi administrasi pembayaran yang dapat mengolah data pembayaran dan memberikan bukti pembayaran untuk menghindari adanya kendala atau kesalahan melakukan pendataan secara akurat dan tepat dan membuat sistem informasi administrasi pembayaran yang dapat mengolah informasi administrasi pembayaran siswa secara optimal serta memiliki fitur pencarian data untuk memudahkan pengguna dalam mencari data dan terjadi efisien waktu.

\section{Diagram Konteks}

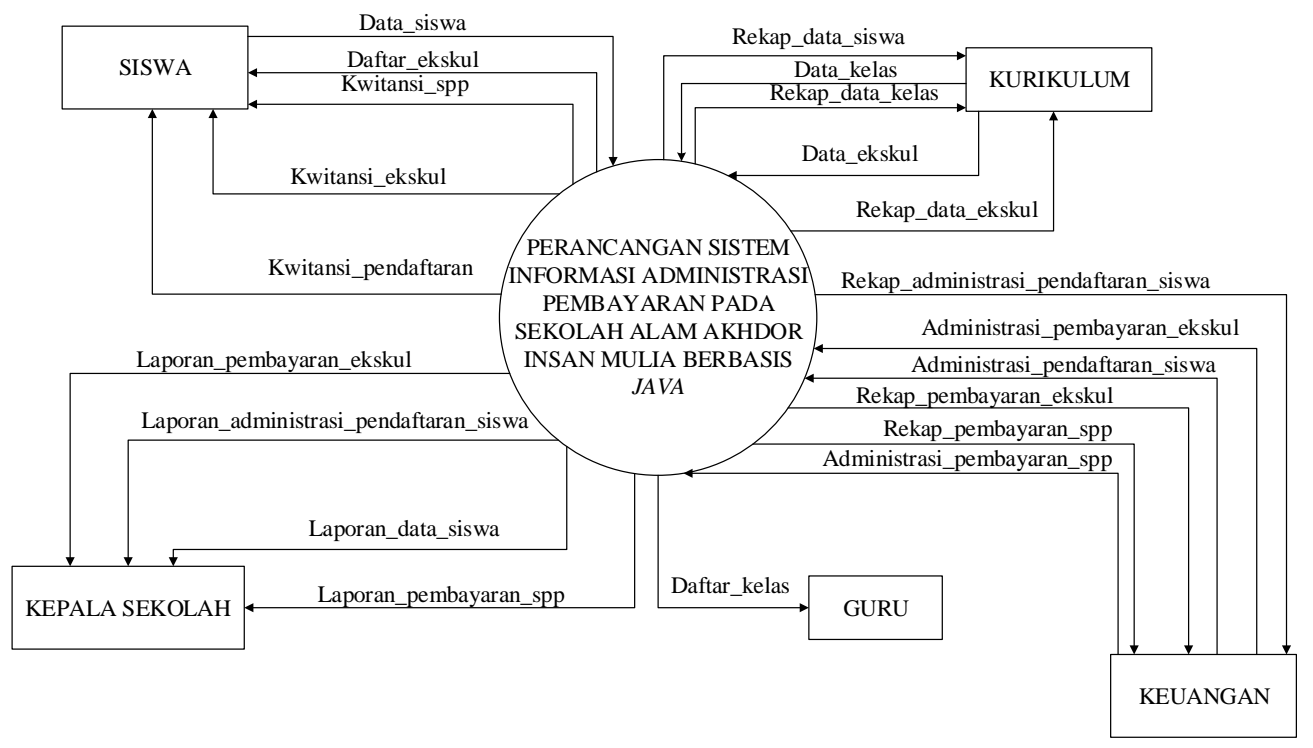

Gambar 1. Diagram Konteks 


\section{Diagram Nol}

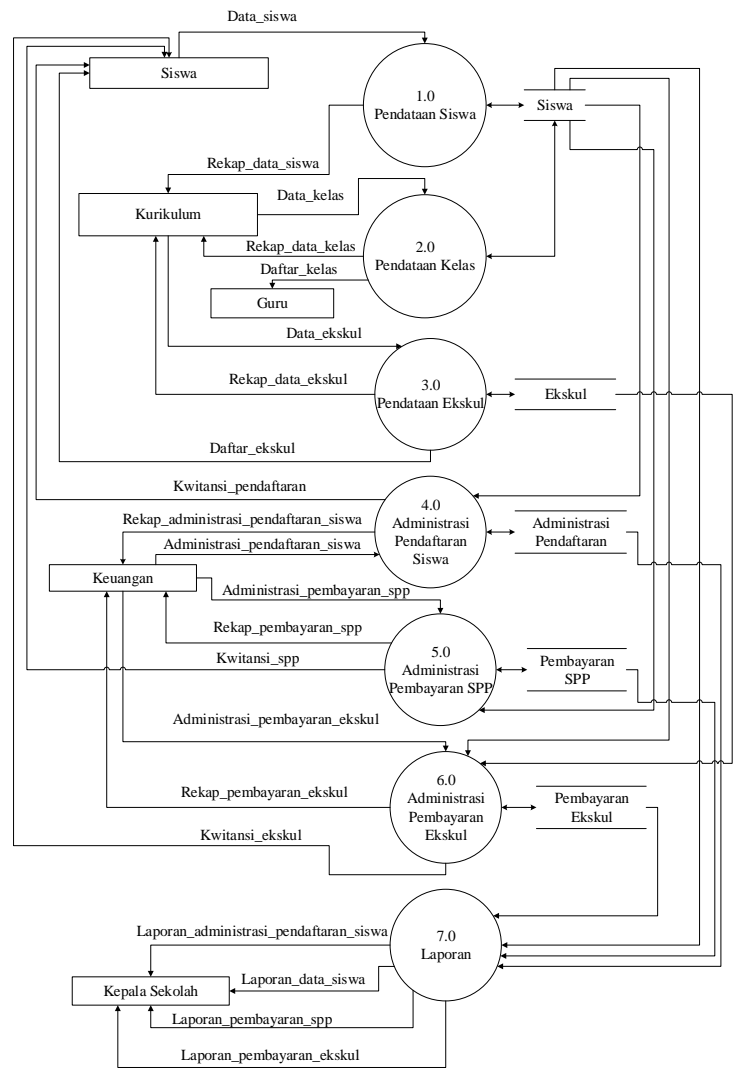

\section{Entity Relationship Diagram}

Gambar 2. Diagram Nol

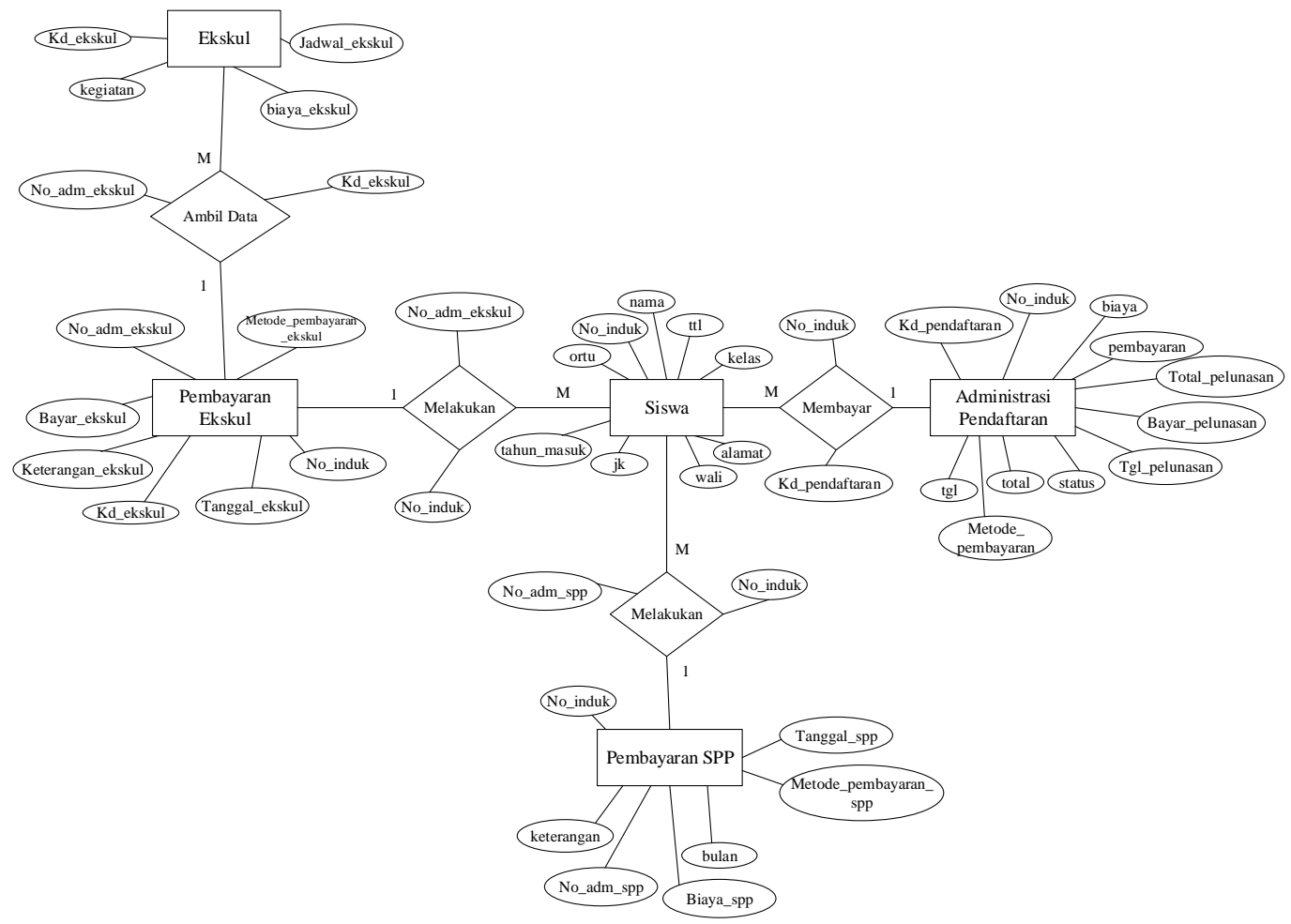

Gambar 3. Entity Relationship Diagram 


\section{Rancangan Layar dan Implementasi Layar}

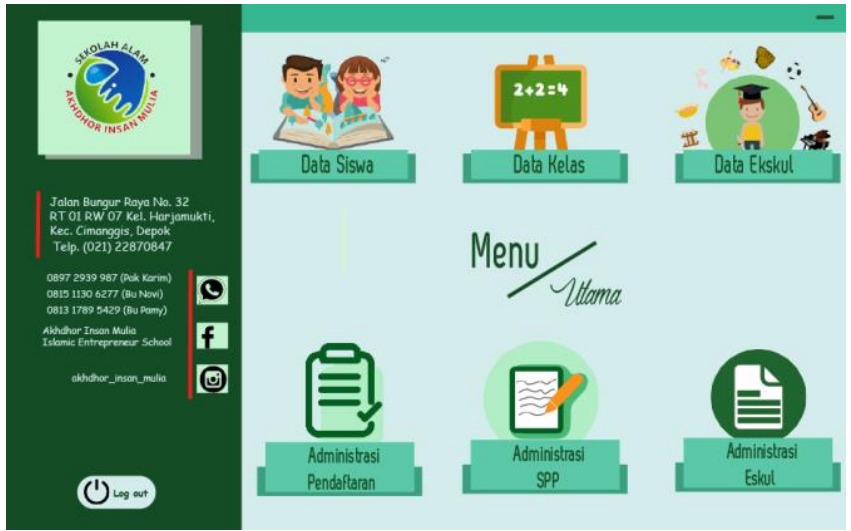

Gambar 4. Tampilan Layar Menu Utama

Tampilan tersebut merupakan tampilan layar menu utama pada sistem.

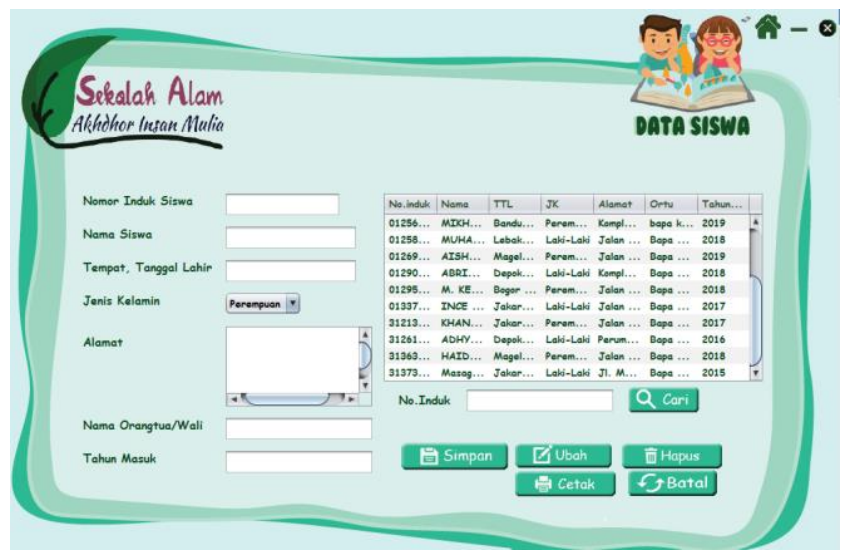

Gambar 5. Tampilan Layar Form Masukan Data Siswa

Tampilan tersebut merupakan tampilan layar form masukan data siswa

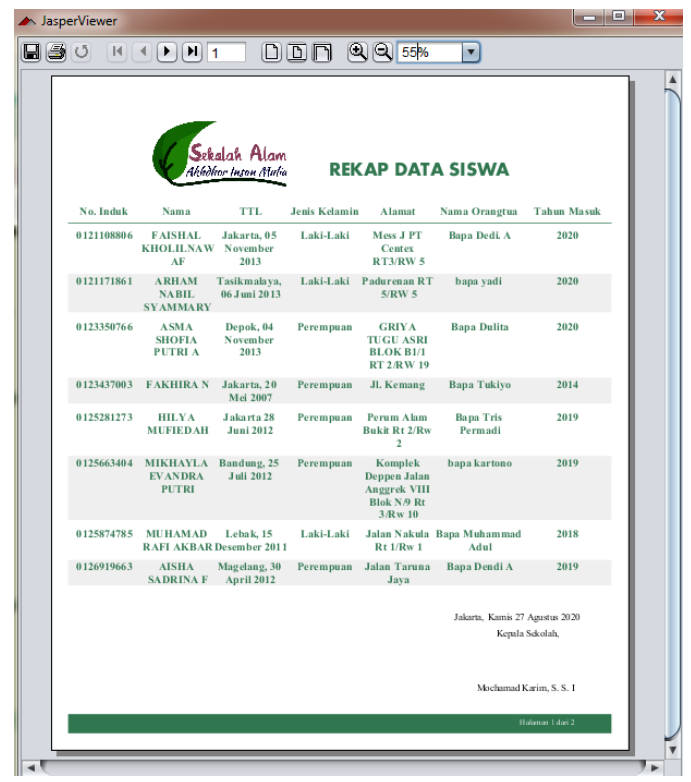

Gambar 6. Tampilan Layar Keluaran Rekap Data Siswa

Tampilan tersebut merupakan tampilan layar keluaran rekap data siswa. 


\section{Jaringan Semantik Tampilan}

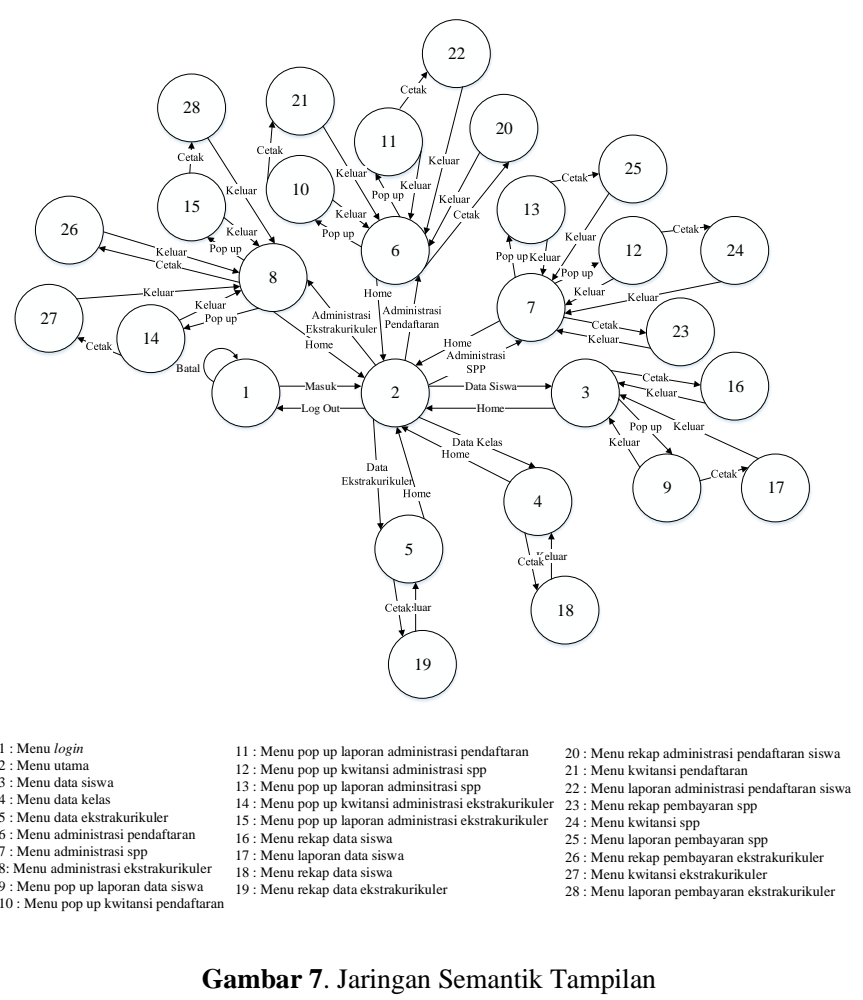

\section{SIMPULAN}

Gambar 7. Jaringan Semantik Tampilan

Sistem Informasi Administrasi Pembayaran Pada Sekolah Alam Akhdhor Insan Mulia Berbasis Java di rancang menggunakan metode Grounded dengan bahasa pemrograman java dengan Netbeans IDE 8.0.2 sebagai editor dan MySQL sebagai basis data sehingga dalam pengolahan data dan informasi menjadi lebih akurat, tepat, optimal, mencetak rekap data, laporan, dan bukti pembayaran lebih mudah dan menghindari adanya kendala atau kesalahan. Sistem Informasi Administrasi Pembayaran memudahkan pengguna dalam proses pencarian data sehingga terjadi efisien waktu.

\section{DAFTAR PUSTAKA}

Abdullah. (2015). Rancang Bangun Sistem Informasi. Romney Dan Steinbart, tahun 2016, 7-25.

Baswananda, A. R. (2014). Sistem Pembayaran Spp Berbasis Komputer Pada Program Studi Sistem Informasi Fakultas Ilmu Komputer Universitas Dian Nuswantoro Semarang. Sistem Pembayaran Spp Berbasis Komputer Pada Program Studi Sistem Informasi Fakultas Ilmu Komputer Universitas Dian Nuswantoro Semarang. https://doi.org/10.1016/j.tranpol.2006.07.001

Dewi, I. R., \& Malfiany, R. (2017). Perancangan Sistem Informasi Administrasi Pembayaran Pada Sdit Lampu Iman Karawang Berbasis Visual Basic 6.0. 12(2), 4-12.

Fitriowandi. (2018). Perancangan Sistem Informasi Administrasi Berbasis Java (Studi Kasus : Cv. Teladan Jambi). 6-16.

Kuryanti, S. J. (2014). Perancangan Sistem Informasi Akademik Sekolah Berbasis Web Dengan Java. Jurnal Khatulistiwa Informatika, 2(1), 77-86. http://ejournal.bsi.ac.id/ejurnal/index.php/khatulistiwa/ article/view/1630/1187

Lubis, B. O. (2016). Penerapan Global Extreme Programming Pada Sistem Informasi Workshop, Seminar Dan Pelatihan. 3(September), 234-245.

Mulyanto, Agus. (2015). Rancang Bangun Sistem Informasi. Romney Dan Steinbart, tahun 2016, 7-25.

Rusmana, N. Y., Triyoni, R. A., \& Sukadi. (2014). Pembuatan Sistem Informasi Pengolahan Data Pasien Rawat Jalan Pada Puskesmas Pringkuku Kabupaten Pacitan. Indonsian Journal on Medical Science, 1(1), 40-45.

Susanto, A. (2016). Perancangan Aplikasi Pembayaran Spp Pada Sma N 1 Ambarawa Menggunakan Bahasa Pemrograman Visual Basic 6.0. Konferensi Mahasiswa Sistem Informasi, 4(1), 819-824. https://doi.org/10.1017/CBO9781107415324.004

Trisnadi, F., Informatika, P. S., Gedong, K., Rebo, P., \& Timur, J. (2020). Perancangan Aplikasi Pendaftaran Service Motor Dan Metode pengumpulan data Metode pengumpulan data yang digunakan sebagai berikut : kepada karyawan . 01(02), 282-287. 